REGULAR ARTICLE

\title{
POLYPHENOLIC PROFILE, SUGAR CONSUMPTION AND ORGANIC ACIDS GENERATION ALONG FERMENTATION OF INFUSIONS FROM GUAVA (PISIDIUM GUAJAVA) BY THE KOMBUCHA CONSORTIUM
}

\author{
MARTHA ROCÍO MORENO-JIMÉNEZa, NURIA ELIZABETH ROCHA-GUZMÁNa, \\ RUTIAGA-QUIÑONES, JOSÉ GUADALUPEb, DANIELA MEDRANO-NÚÑ̃̃a, \\ JUAN ANTONIO ROJAS-CONTRERAS ${ }^{\text {, }}$ RUBÉN FRANCISCO GONZÁLEZ-LAREDOa, \\ JOSÉ ALBERTO GALLEGOS-INFANTE ${ }^{*}$
}

aTecNM/Instituto Tecnológico de Durango, Dpto. de Ings. Química y Bioquímica, UPIDET, Blvd. Felipe Pescador 1830 Ote. Col Nueva Vizcaya, 34080 Durango, Dgo, México

bFacultad de Ingeniería en Tecnología de la Madera. Universidad Michoacana de San Nicolás de Hidalgo. Apartado Postal 580. 58000 Morelia, Michoacán. México

\begin{abstract}
The kombucha beverage is usually prepared from black tea, with sucrose, inoculated with previously fermented liquid broth and/or tea fungus pellicle, and incubated. Alternative sources have been used for kombucha beverages. Guava leaves have been used for long time as traditional medicine. It is found in many commercially available botanical supplements in form of decoction, milled and used as comprises. They are rich in polyphenolic compounds. Several changes are produced during fermentation of the beverages. The main objective of the present work is to characterize fermentation process of guava leaves infusions by kombucha and studying possible chemical changes in their polyphenolic profile. Infusions from guava leaves were prepared and fermented by the kombucha consortium. The $\mathrm{pH}$, titrable acidity, polyphenolic compounds, sugar consumption, organic acid along the fermentation was made by UPLC-ESI-MS. Kombucha from Camellia sinensis (CS) was made as a control. Higher rate of sucrose consumption was observed for Kombucha made with CS, also, higher production of organic acids (acetic and succinic acid) was observed too. Both behaviors were related to the content of glucose. The flavan-3-ols were diminishing along the fermentation time, with the exception of epigallocatechin in Camellia sinensis, Flavan-3-ol content in Guava leaves was low. Higher content of dicaffeoyl quinnic acid was observed for both systems in special for CS, falling after a maximum peak; minor constituents of hydroxycinnamic acids were stable along the fermentation for both systems.
\end{abstract}

Keywords: Fermentation, Guava leaves, Kombucha, Polyphenols

\section{INTRODUCTION}

Guava (Psidium guajava) is a fruit that grows in tropical countries. The variety of fruit dictates its shape (i.e. round, oval, or pear-shaped), diameter (approximately 1-4 in), and color (i.e. pink, white, yellow, salmon, or deep red color) [1]. Psidium guajava L. (guava) leaves have been used for a long time as traditional medicine in form of decoction, milled and used as comprises, etc., currently they are still employed [2]. Guava leaves after drying is suitable as a botanical supplement. Several biological activity studies showed that guava leaves have important beneficial healthy effects as anti-inflammatory, hypoglycemic, antibacterial, antidiarrheal and antioxidant properties [3-5] indicated that in India, guava leaves were used to treat skin wounds and alleviate toothaches.

The leaves contain antimicrobial components effective against Staphylococcus aureus that may ward off infection, and its tannin content may promote healing. Indigenous people from Southeast Asian countries consumed the fruit to reduce or prevent hypertension and to fight influenza infection. In Malaysia, guava leaves are used in an astringent solution to treat diarrhea and stomach ache. Researchers have also reported the use of guava leaves to expel the placenta during child birth [5]. Other health conditions related to guava use were reviewed by [6] who suggested that different plant constituents, usually the leaves, may exhibit antidiabetic, antimicrobial, antidiarrheal, and anti-cough properties.

Similarly, some in vivo studies have proved the antiinflammatory action of extracts, essential oils, or steam distilled components of guava leaf $[7,8]$. About studies on its phytochemical profile, several authors report presence of flavonoids, in special, quercetin $[9,10]$ in guava leaves. In contrast, the guava leaves fermentation process showed

Received 26 December 2017; Accepted 28 February 2018

${ }^{*}$ Corresponding Author

Jose Alberto Gallegos Infante

TecNM/Instituto Tecnológico de Durango, Dpto. de Ings. Química y Bioquímica, UPIDET, Blvd. Felipe Pescador 1830 Ote. Col Nueva Vizcaya, 34080 Durango, Dgo, México

Email: agallegos@itdurango.edu.mx

(This article is open access and licensed under the terms of the Creative Commons Attribution License (http://creativecommons.org/licenses/by/4.o/) which permits unrestricted, use, distribution and reproduction in any medium, or format for any purpose, even commercially provided the work is properly cited. Attribution - You must give appropriate credit, provide a link to the license, and indicate if changes were made. 
a lack of knowledge. In a previous study, $P$. linteus mycelium was grown with guava leaf as a substrate, and was later fermented with Lactobacillus plantarum and Saccharomyces cerevisiae for developing fermented guava leaf extracts [2]. However, they do not described changes produced during the fermentation process, particularly on the chemical composition.

The kombucha drink is mainly prepared from black tea (1$2 \%)$, sucrose $(5-10 \%)$ and with fermented liquid broth (10-20\%) and/or tea fungus pellicle (2.5-5.0\%), and incubated at $25-37^{\circ} \mathrm{C}$ for $7-12 \mathrm{~d}$ [11].

There are previous reports about health improvement, disease treatments etc $[12,13]$. In earlier reports, Thymus vulgaris L., Lippiacitriodora, Rosmarinus officinalis, Foeniculum vulgare and Mentha piperita [14] and Quercus resinosa [15] were used as substrates to produce kombucha tea.

From our best knowledge, there is only one report about the use of guava leaves and kombucha consortium [16], they tested antioxidant activity of kombucha analogues from guava leaves by DPPH method, finding an increase after $14 \mathrm{~d}$ of fermentation. However, the behavior of polyphenolic profile and sugar and organic acids in the kombucha analogues from guava leaves was unknown. The main objective of the present work is to characterize fermentation process of guava leaves infusions by kombucha and studying possible chemical changes in the present polyphenol compounds.

\section{MATERIALS AND METHODS}

Psidium guajava leaves were collected from Michoacán state, Mexico, during the spring of 2014. Leaves were dried at room temperature, milled and stored until their use.

\section{Infusions}

Decoctions were obtained by putting $2 \%(\mathrm{w} / \mathrm{v})$ of milled dry guava leaves into water at $80{ }^{\circ} \mathrm{C}$ by $10 \mathrm{~min}$ [17]. Afterwards, obtained infusion was paper filtered (whatman, \# 1).

\section{Fermentation conditions}

The starting kombucha consortium was maintained in sweetened (sucrose $10 \% \mathrm{w} / \mathrm{v}$ ) black tea at $25{ }^{\circ} \mathrm{C}$. Freshly cultured kombucha was used for further subcultures or fresher fermentation batches. Fermentation conditions were time $11 \mathrm{~d}$, with $10 \%(\mathrm{w} / \mathrm{v})$ of sucrose, inoculum $(2.5 \% \mathrm{w} / \mathrm{v}$, Kombucha consortium) and incubation temperature of $22{ }^{\circ} \mathrm{C}$. Total volume of fermented guava leaves was $0.5 \mathrm{~L}$.

\section{Chemical Analysis}

Flavonoid analysis was performed following the standard method [18].

\section{Sugar analysis}

Carbohydrates analysis was made by the use of Acquity UPLC (Waters Corp. Milford, MA, USA) coupled to mass tandem Xevo TQ-S triple quadrupole (Waters Corp.). Column used was Acquity BEH amida $100 \mathrm{~mm} \times 2.1 \mathrm{~mm}$, $1.7 \mu \mathrm{m}$ (Waters Corp.) at $35{ }^{\circ} \mathrm{C}$. Elution profile was acetonitrile: water with $0.1 \%$ of ammonium hydroxide (80:20) (A) and acetonitrile: water with $0.1 \%$ of ammonium hydroxide (30:70) (B): gradient of 5-60\% B in $5 \mathrm{~min}, 60 \%$ B by $1 \mathrm{~min}$, after that $60-5 \%$ B by $0.5 \mathrm{~min}$, and finally standby for $5 \mathrm{~min}$. Flow rate was $0.25 \mathrm{ml} / \mathrm{min}$. MRM data were registered from o to $12 \mathrm{~min}$. Evaluation was made in negative mode of ionization. ESI conditions were capillary voltage $2.85 \mathrm{kV}$, desolvation temperature $500{ }^{\circ} \mathrm{C}$, source temperature $150^{\circ} \mathrm{C}$, gas flow of desolvation and cone $794 \mathrm{~L} / \mathrm{h}$ y $151 \mathrm{~L} / \mathrm{h}$, collision gas $0.14 \mathrm{ml} / \mathrm{min}$ (gas used was argon grade). Pure samples of saccharose, glucose and fructose were used as standards. Control and data analysis were made by use of software MassLinx (Waters Corp.).

\section{Organic acids}

Organic acids evaluation was performed according to [19]. Briefly, $20 \mu \mathrm{L}$ of sample were poured into eppendorf tube, followed by $10 \mu \mathrm{L}$ of 3 -nitrophenylhydrazine $(3 \mathrm{NPH} \bullet \mathrm{HCl})$ $40 \mathrm{mmol}$ and $10 \mu \mathrm{L}$ of 1-ethyl-3-(3-dimethylaminopropyl) carbodiimide (EDC• $\mathrm{HCl}) 37.5 \mathrm{mmol}$ with $1.5 \%$ of pyridine. The blend was incubated at $40{ }^{\circ} \mathrm{C}(30 \mathrm{~min})$, then frozen in an ice bath (1 min), and added with $960 \mu \mathrm{L}$ of acetonitrile: water (10:90), before filtration.

Chromatographic analysis was done in an Acquity UPLC (Waters Corp. Milford, MA, USA) coupled to a mass tándem system (Xevo TQ-S triple quadrupole, Waters Corp.), using a column Acquity HSS C18 100 mm x 2.1 $\mathrm{mm}, 1.7 \mu \mathrm{m}$ (Waters Corp.) at $40{ }^{\circ} \mathrm{C}$. The elution program, included two solvents; acidified water with formic acid (99.99:0.01 v/v) (A) and acetonitrile: formic acid (99.99:0.01 v/v) (B), following the next elution profile: $0-2$ min $85 \%$ of $A$ and $15 \%$ of $\mathrm{B}, 2-11$ min $45 \%$ of $A$ and $55 \%$ of B, 11-12 min $100 \%$ of $B$ and $12-15$ min $85 \%$ of $A$ and $15 \%$ of B. Using acetic acid as standard. Data analysis was made by the use of MassLinx software (Waters Corp.).

\section{Yeast analysis}

Yeasts were isolated using Potato-dextrose (PDA) agar incubated at $28{ }^{\circ} \mathrm{C}$ for $24 \mathrm{~h}$. Isolated yeasts were used to obtain genomic DNA by the method of [20]. It was amplified the gene $5.8 \mathrm{~S}$ rARN, adding 50 ng of DNA to the mix of PCR until final volume of $50 \mu \mathrm{l}$ : $50 \mathrm{mmol}$ ITS 1 ( $5^{\prime}$ TCCGTAGGTGAACCTGCGG-3'), 50 mmol ITS4 (5' TCCTCCGCTTATTGATATGC-3') (Invitrogen), $0.25 \mathrm{mmol}$ of mix of dNTP, 1 X Buffer Taq with $\left(\mathrm{NH}_{4}\right)_{2} \mathrm{SO}_{4}(750 \mathrm{mmol}$ Tris- $\mathrm{HCl} \mathrm{pH} \mathrm{8,8,} 200 \mathrm{mmol}\left(\mathrm{NH}_{4}\right)_{2} \mathrm{SO}_{4}, 0.1 \%$ Tween 20), $2.5 \mathrm{mmol} \mathrm{MgCl}_{2}$, and $1 \mathrm{U}$ of Taq Polimerase (Fermentas, USA). The amplified product was analyzed by restriction analysis using enzymes Hind1 and Hae1. Digestion products were analyzed by electrophoresis agarose gel (1.5\%), stained with ethidium bromide and visualized by UV transilluminator and camera with UV filter. Band sizes were analyzed using molecular weight standard Invitrogen 10opb. The size was evaluated in pair of bases and the stripes obtained were compared with identified yeast.

\section{Data analysis}

Hydroxycinnamic acid, succinic acid and glucose data (4O-caffeoylquinnic acids) were analyzed by Spearman correlation analysis. Multiple linear regression analysis was used for glucose and succinic acids. One-way anova and Tukey test $(\mathrm{p}<0.05)$ was used for data analysis.

\section{RESULTS AND DISCUSSION}

\section{Carbohydrates}

The obtained results for sugars (sucrose, fructose and glucose) are shown on fig. 1 a,b. Sucrose consumption behavior in Camellia sinensis kombucha (CS) (fig. 1a) was different to the previously observed by [21]. They did not observe oscillating behavior of sucrose along the 
fermentation time, as can be seen on the results of the present experiment. The differences could be related in function of different strain used for fermentation, because [21] used a Saccharomyces strain, in contrast, in the present work, it was used a kombucha consortium. Main microorganism present in the consortium is Acetobacter xylinum. This microorganism has been reported with strong sucrose synthesis activity in presence of glucose, fructose, inorganic phosphate and disaccharide glucosyltransferase [22].

It is interesting that the oscillating behavior was present after three days for Camellia sinensis fermented infusions but was not for Psidium guajava fermented infusions (fig. $1 \mathrm{~b}$ ). Also, it is important to note, that the rate of sucrose consumption was faster in Camellia sinensis in comparison to Psidium guajava (at day 3, CS $10 \mathrm{~g} / \mathrm{l}, \mathrm{PG}$ $38 \mathrm{~g} / \mathrm{l}$ of residual sucrose).

\section{Organic acids}

Succinic acid (SA) plus acetic acid (AA) production reached a maximum amount after $9 \mathrm{~d}$ in guava leaves kombucha (GK) fermentation. On the other hand, the maximum amount of SA+AA in kombucha from Camellia sinensis $(6.8 \mathrm{~g} / \mathrm{l})$, was observed at $5^{\text {th }}$ day of fermentation (fig. 2 a,b). After that, Camellia kombucha has shown a reduction in the amount of SA+AA thru the end of fermentation; An opposite behavior was observed by guava, that remained almost stable until day 5 of fermentation, followed by an increase in concentration of organic acids at day 9 of fermentation, and a decrease by the end of fermentation time $(11 \mathrm{~d})$. At this point, no differences were observed on SA+AA content between Guava leaves and Camellia kombucha. The presence of organic acids as succinic acid and acetic acid is a function of strain and substrate [23]; these authors claim that a slow growth of Acetobacter diminishes the presence of organic acids. However, in the present work, at the end of fermentation time no differences were observed about succinic acid+acetic acid. $\mathrm{SA}+\mathrm{AA}$ can act as fermentation end-products for a selection of microorganism, in special bacteria, however, several strains such as Saccharomyces cerevisiae have been reported as organic acids producers, at lower yield than bacteria in sake production [24].

Also, results about presence of yeast at the time of fermentation (guava kombucha) are shown in table I. At day 3 of fermentation, Saccharmoyces cerevisiae was observed in guava kombucha, which has been reported as producer of organic acids. After that (i.e. day 7) Shizosaccharomyces and Pichia angophorae were present in guava kombucha, and under acidic conditions these yeasts can produce succinic acid [25]. Thus, it is possible that organic acids present at the beginning of fermentation (until day 3) were produced by Saccharomyces cerevisiae in CS kombucha. However, in the Guava kombucha, Pichia angophorae (present at day 7 and 9) is a yeast that produces important amount of ethanol but in presence of oxygen, may produce high amount of organic acids [26].
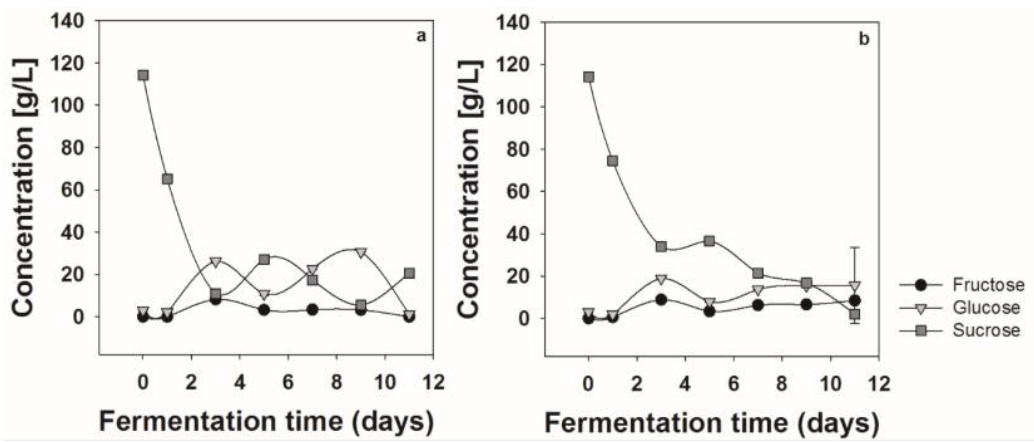

Fig. 1: Concentration of fructose, glucose and sucrose in (Camellia sinensis) (a), (Guava leaves) (b) infusions fermented by kombucha consortium along the time

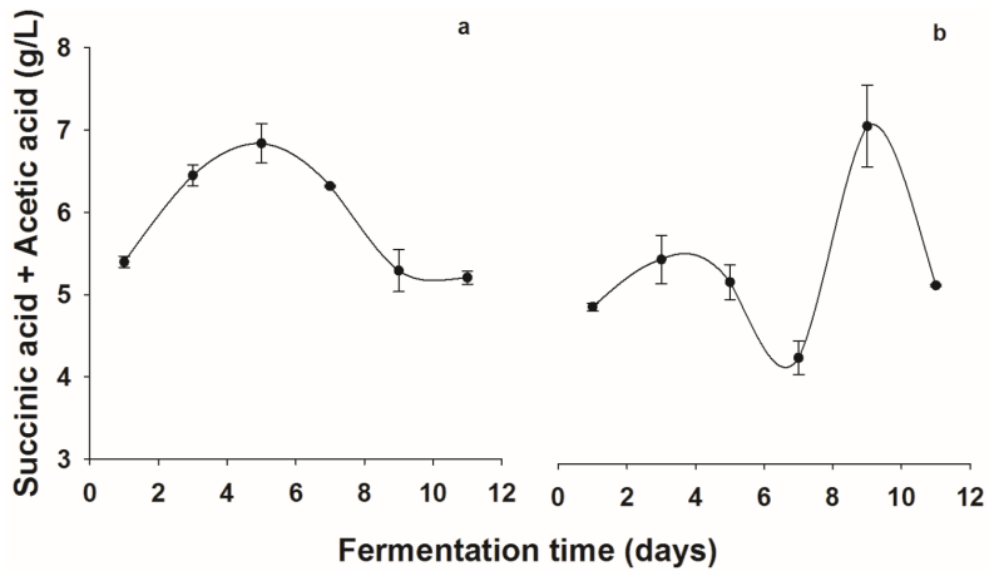

Fig. 2: Concentration of organic acids through the fermentation time of (Camellia sinensis) (a) and (guava leaves) (b) 
Table 1: Presence of yeast along the fermentation time

\begin{tabular}{lll}
\hline Fermentation day & Gender & Specie \\
\hline 1 & Dekkera & Anómala \\
1 & Shizosacharomyces & Pombe \\
1 & Torulospora & Protoriensis \\
& & ludwigii \\
3 & Sacharomyces & Angophorae \\
3 & Piquia & pombe var. Pombe \\
3 & Shizosacharomyces & ludwigii \\
3 & Sacharomyces & Pombe \\
5 & Shizosacharomyces & delbrueckii \\
5 & Torulospora & Protoriensis \\
5 & Torulospora & pombe var. Pombe \\
5 & Shizosacharomyces & pombe var. Pombe \\
7 & Shizosacharomyces & Angophorae \\
7 & Piquia & Protoriensis \\
7 & Torulospora & anomala \\
7 & Dekkera & Pombe \\
9 & Shizosacharomyces & delbrueckii \\
9 & Torulospora & Protoriensis \\
9 & Torulospora & Angophorae \\
9 & Piquia & boindinii \\
11 & Candida & Pombe \\
11 & Shizosacharomyces & Angophorae \\
11 & Piquia & Protoriensis \\
11 & Torulospora & Angophorae \\
11 & Piquia &
\end{tabular}

\begin{tabular}{lll}
\hline Fermentation day & Gender & Specie \\
\hline 1 & Dekkera & Anómala \\
1 & Shizosacharomyces & Pombe \\
1 & Torulospora & Protoriensis \\
3 & Sacharomyces & ludwigii \\
3 & Piquia & Angophorae \\
3 & Shizosacharomyces & pombe var. Pombe \\
3 & Sacharomyces & ludwigii \\
5 & Shizosacharomyces & Pombe \\
5 & Torulospora & delbrueckii \\
5 & Torulospora & Protoriensis \\
5 & Shizosacharomyces & pombe var. Pombe \\
7 & Shizosacharomyces & pombe var. Pombe \\
7 & Piquia & Angophorae \\
7 & Torulospora & Protoriensis \\
7 & Dekkera & anomala \\
9 & Shizosacharomyces & Pombe \\
9 & Torulospora & delbrueckii \\
9 & Torulospora & Protoriensis \\
9 & Piquia & Angophorae \\
11 & Candida & boindinii \\
11 & Shizosacharomyces & Pombe \\
11 & Piquia & Angophorae \\
11 & Torulospora & Protoriensis \\
11 & Piquia & Angophorae \\
\hline
\end{tabular}

\section{Phenolic compounds}

Results about flavan-3ols behavior along the fermentation are shown in fig. 3a, b. At the beginning of the fermentation, epicatechin was the most abundant flavan-3-ol present in Camellia sinensis kombucha (fig. 1 a) as expected. However, its concentration was diminishing after day 1 until about $60 \%$ of the initial amount of epicatechin. After that, the amount of epicatechin was stable until the end of fermentation process (day 11). Similar behavior was observed for gallocatechin and catechin measured in the present experiment, i.e. a strong reduction at the first day of fermentation; except for galocatechin gallate and epicatechin gallate, they showed an increase at the first day of fermentation (CSK). 

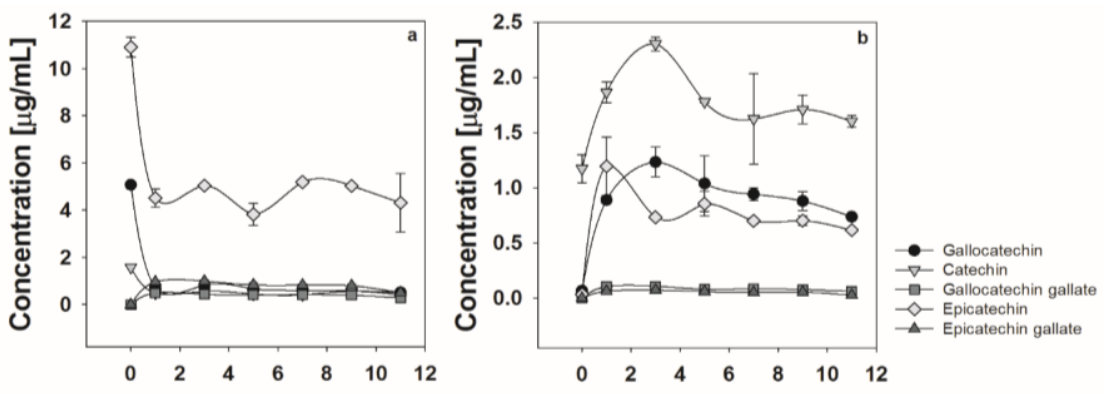

Fermentation time (days)

Fermentation time (days)
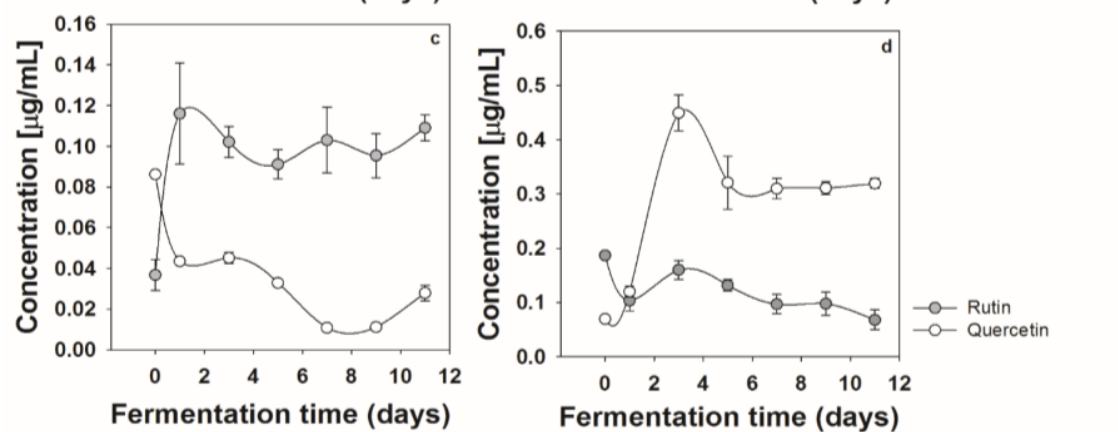

Fig. 3: Concentration of flavonoids, left side (a and c) (Camellia sinensis) and right side (b and d) (guava leaves)

The stability of flavan-3-ols has been reported by several authors. pH-driven degradation of EGCG and EGC is thought to proceed by oxidative mechanisms involving the donation of $\mathrm{H} \cdot$ to quench oxygen radicals, thus, catechins holding catechol B-ring structures (EC and ECG) are more stable [27]. An interesting explanation on the behavior of flavan-3-ol in fermented beverages was done by [28]. They demonstrated that monomers of several flavan-3-ols can form colloidal aggregates in special gallocatechin gallate and the formation of self-agglomerates may be a function of the ethanol concentration, i.e. at low concentration of ethanol $(2 \% \mathrm{v} / \mathrm{v})$, there is an increase of surface tension, driving to the formation of agglomerates, but at higher levels of ethanol, tension surface diminishes, stopping the aggregate formation. About this fact, is possible that some aggregates of flavan-3-ols were obtained, and in function of this behavior, a lower content in the experimental samples were detected.

On the other hand, the behavior of flavan-3-ols tannins was not observed for guava fermented kombucha. This different behavior could be related with the notable differences in the amount of flavan-3-ols in both beverages, CS is very rich, while guava leaves is poor in flavan-3-ols.

Results about hydroxycinnamic acids are shown in fig. 4 a,b. Important differences were observed between guava leaves and Camellia sinensis. About behavior of kombucha from CS (fig. 4a), there is great content of dicaffeoyl quinnic derivate at the beginning of fermentation, inclusive at day 3 there is an increase (up to $38 \mu \mathrm{g} / \mathrm{ml}$ ), after that, there is a reduction until similar levels to another hydroxycinnamic acids. In comparison to GL fermented (fig. 4b), it was observed the presence of dicaffeoyl quinic acid at lower amounts, but it was observed a light increase of DQ compound at day 5 of fermentation. Subsequently, it was observed a decrease to levels similar to other hydroxycinammic acids present in the fermented infusion. It was interesting that a correlation analysis showed a high relationship between 4O-caffeoyil quinnic acid and organic acids $(r=0.91)$ for kombucha from Camellia sinensis. Also, it should be mentioned that succinic acid was related with the glucose content, thus, the changes in content of 4-O-caffeoyil quinnic acid could be related with the metabolism of yeast, in special Saccharomyces cerevisiae. On the other hand, the behavior of caffeoyl quinnic acid was also related to the presence of succinic acid $(\mathrm{r}=0.87)$. However, the initial amount of hydroxycinnamic acids is lower than Camellia sinensis, therefore, the level of derivates of caffeic acid are lower in Psidium guajava leaves.

Several reports about hydroxycinnamic acids of fermented beverages has been published, in special related with wine fabrication; however in general, papers report on diminishing amounts of hydroxycinnamic acids associated with enzyme activity (i.e. hydrolases and decarboxylases associated to yeast and lactic bacteria) [29;30;31] and an increase of caffeic acid, however in the present work, caffeic and coumaric acids were stable along the fermentation time in both fermented beverages (CS and GL). However, [32] reported an increase of 5 -O-cafeoylquinic acid in coffee brews related with the coffee cultivar, also, [33] reported an increase of different compounds resulted from several reactions between 5 -Ocaffeoyilquinnic acid and hot water, these reactions are dependent on the $\mathrm{pH}$; these differences were observed at the time of infusion, not subjected to the fermentation process.

Several fermentation processes have been related with the increase of some phenolic compounds, [34] fermented green tea with Aspergillus oryzae and found an increase of several derivates of quinnic acid. More research is needed on the metabolic changes of hydroxycinnamic acids under fermentation by the kombucha consortium and their relationship with yeast, in special Saccharomyces cerevisiae. 

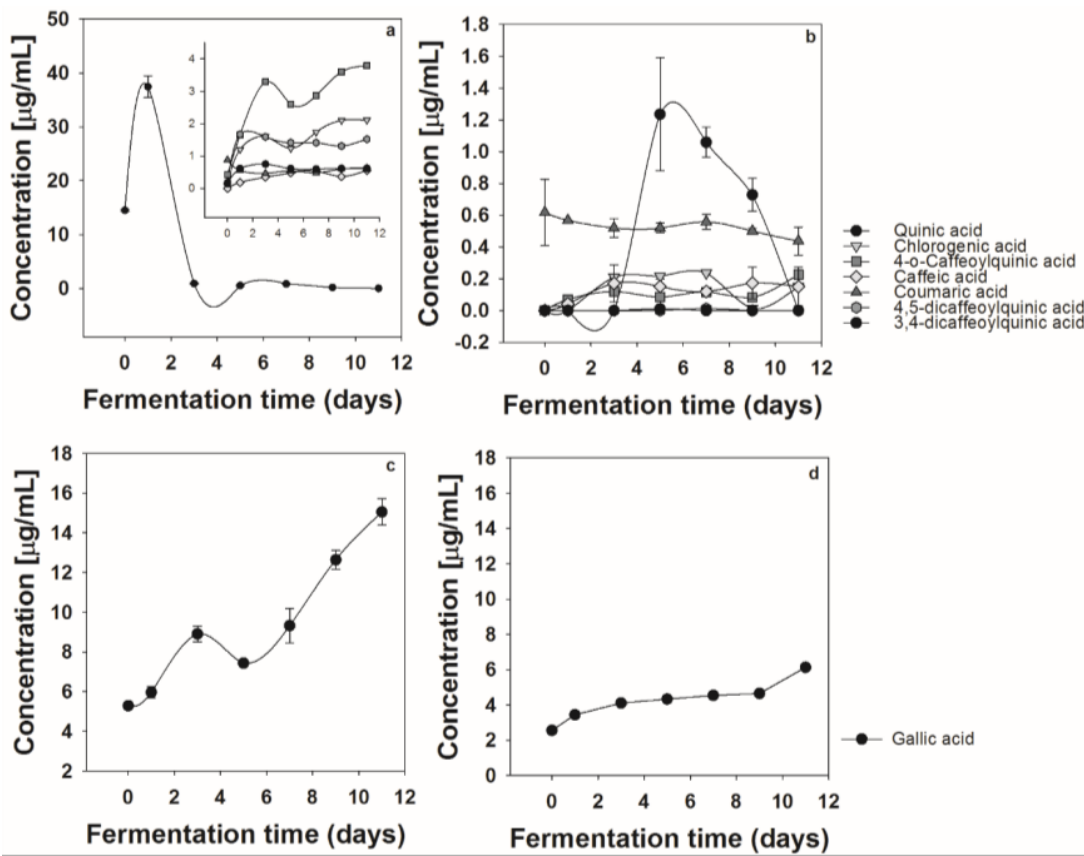

Fig. 4: Concentration of hydroccinamic acids and gallic acid along fermentation of left side (a and c) (camellia sinensis), right side (guava leaves) (b and d)

\section{CONCLUSION}

The rate of sucrose consumption was higher for kombucha made with Camellia sinensis in comparison to fermented guava leaves. This fact affected the kinetical behavior of carbohydrates (fructose and glucose), and therefore the organic acids production was affected consequently by the kinetics of carbohydrates production and consumption. Finally, the production of organic acids affects the pH of the system, and this factor along others modifies the stability of the polyphenol compounds present.

\section{ACKNOWLEDGEMENT}

DMN Acknowledgement scholarship by CONACyT, Project was partially funded by TecNM grant and CONACyT Infrastructure grant.

Conflict of interest: None.

\section{REFERENCES}

1. Mercadante AZ, Steck A, Pfander H. Carotenoids from Guava (Psidium guajava L.): Isolation and Structure Elucidation. Journal of Agricultural and Food Chemistry. 1999;47:145-151.

2. Choi SY, Hwang JH, Park SY, Jin YJ, Ko HC, Moon SW, Kim SJ. Fermented guava leaf extract inhibits LPS-induced COX-2 and iNOS expression in Mouse macrophage cells by inhibition of transcription factor NF-kB. Phytoterapy Research. 2008;22:1030-1034.

3. Qian H, Nihorimbere V. Antioxidant power of phytochemicals from Psidium guajava leaf. Zhejiang University Science. 2004;5:676-83.

4. Ojewole, J. A. O. Hypoglycemic and hypotensive effects of Psidium guajava Linn. (Myrtaceae) leaf aqueous extract. Methods and Findings in Experimental Clinical Pharmacology. 2005;27:689-696.

5. Lim TK, Khoo KC. Guava in Malaysia: Production, Pests and Diseases. 1990, Kuala Lumpur: Tropical Press, Malaysia.
6. Gutiérrez RMP, Mitchell S, Solis RV. Psidium guajava: a review of its traditional uses, phytochemistry and pharmacology. Journal of Ethnopharmacology. 2008;117:1-27.

7. Kavimani S, Karpagam RI, Jaykar B. Antiinflammatory activity of volatile oil of Psidium guajava. Indian Journal of Pharmaceutical Sciences. 1997;59:142-144.

8. Muruganandan S, Srinivasan K, Chandra S, Tandan SK, Lal J, Raviprakash V. Antiinflammatory activity of Syzygium cumini bark. Fitoterapia. 2001;72:369-377.

9. Lozoya X. Two decades of Mexican ethnobotany and research in plant drugs. Ethnobotany and the search for New Drugs. Chadwick and Marsh Eds 1994;130-152, Wiley.

10. Begum S, Hassan SI, Siddiqui BS, Shaheen F, Ghayur MN, Gilani AH. Triterpenoids from the leaves of Psidium guajava. Phytochemistry. 2002;61:399-403.

11. Kallel L, Desseaux V, Hamdi M, Stocker P, Ajandouz EH. Insights into the fermentation biochemistry of Kombucha teas and potential impacts of Kombucha drinking on starch digestion. Food Research International. 2012;49:226-232.

12. Jayabalan R, Marimuthu S, Swaminathan K. Changes in content of organic acids and tea polyphenols during kombucha tea fermentation. Food Chemistry. 2007;102:392-398.

13. Velićanski A, Cvetković DD, Markov S, Tumbas TV, Savatović S. Antimikrobna i antioksidativna aktivnost kombuhe od melise. Acta Periodica Technologica. 2007;38:165-172.

14. Battikh H, Bakhrouf A, Ammar E. Antimicrobial effect of kombucha analogues. LWT-Food Science and Technology. 2012;47:71-77.

15. Vázquez-Cabral BD, Rocha-Guzmán NE, GallegosInfante JA, González-Herrera SM, González-Laredo RF, Moreno-Jiménez MR, Córdova-Moreno IT. Chemical and sensory evaluation of a functional beverage obtained from infusions of oak leaves (Quercus resinosa) inoculated with the kombucha consortium under 
different processing conditions. Nutrafoods. 2014;13:169-178.

16. Suhardini PN, Zubaidah E. Studi aktivitas antioksidan kombucha dari berbagai jenis daun selama fermentasi. 2016;Jurnal Pangan dan Agroindustri, 4:221-229.

17. Rocha-Guzmán NE, Gallegos-Infante JA, GonzálezLaredo RF, Reynoso-Camacho R, Ramos-Gómez M, Garcia-Gasca T, Rodriguez-Muñoz ME, GuzmanMaldonado SH, Medina-Torres L, Lujan-García BA. Antioxidant activity and genotoxic effect on HeLa cells of phenolic compounds from infusions of Quercus resinosa leaves. Food Chemistry. 2009;115:1320-1325.

18. Vazquez-Cabral D, Valdez-Fragoso A, Rocha-Guzman NE, Moreno-Jimenez MR, Gonzalez-Laredo RF, Morales-Martinez PS, Rojas Contreras JA, Mujica-Paz $\mathrm{H}$, Gallegos-Infante JA. Effect of pulsed electric field (PEF)-treated kombucha analogues from Quercus obtusata infusions on bioactives and microorganisms. Innovative Food Science and Emerging Technology. 2016;34:171-179.

19. Ye M, Yue T, Yuan Y. Evolution of polyphenols and organic acids during the fermentation of apple cider. Journal of the Science of Food and Agriculture. 2014;94:2951-2957.

20. Stulnig TM, Amberger A. Exposing contaminating phenol in nucleic acid preparations. Biotechniques. 1994;16:402-404.

21. Sevda SB, Rodrigues L. Fermentative behavior of Saccharomyces strains during guava (Psidium guajava L) must fermentation and optimization of guava wine production. Journal of Food Process and Technology. 2011;2:2-10

22. Vandamme EJ, Loo JV, Simkens E, Laporte, A. D. Optimization of sucrose phosphorylase production by Leuconostoc mesenteroides. Journal of Chemical Technology and Biotechnology. 1987;39:251-262.

23. Jayabalan R, Malbaša RV, Lončar ES, Vitas JS, Sathishkumar M. A review on kombucha teamicrobiology, composition, fermentation, beneficial effects, toxicity, and tea fungus. Comprehensive Reviews on Food Science and Food Safety. 2014;13:538-550.

24. Raab AM, Gebhardt G, Bolotina N, Weuster-Botz D, Lang C. Metabolic engineering of Saccharomyces cerevisiae for the biotechnological production of succinic acid. Metabolic Engineering. 2010;12:518525 .

25. Taing O, Taing K. Production of malic and succinic acids by sugar-tolerant yeast Zygosaccharomyces rouxii. European Food Research and Technology. 2007;224:343-347

26. Horn S J, Aasen IM, Østgaard K. Ethanol production from seaweed extract. Journal of Industrial Microbiology and Biotechnology. 2000;25:249-254.

27. Neilson AP, Ferruzzi M G. Influence of formulation and processing on absorption and metabolism of flavan-3-ols from tea and cocoa. Annual Reviews Food Science and Technology. 2011;2:125-151.

28. Poncet-Legrand C, Cartalade D, Putaux JL, Cheynier V, Vernhet A. Flavan-3-ol aggregation in model ethanolic solutions: Incidence of polyphenol structure, concentration, ethanol content, and ionic strength. Langmuir. 2003;19:10563-10572.

29. Van Beek S, Priest FG. Decarboxylation of substituted cinnamic acids by lactic acid bacteria isolated during malt whisky fermentation. Applied Environmental Microbiology. 2000;66:5322-5328.

30. Nogueira A, Guyot S, Marnet N, Lequéré JM, Drilleau $\mathrm{JF}$, Wosiacki G. Effect of alcoholic fermentation in the content of phenolic compounds in cider processing. Brazilian Archives Biology and Technology. 2008;51:1025-1032.

31. Harris V, Ford CM, Jiranek V, Grbin PR. Dekkera and Brettanomyces growth and utilisation of hydroxycinnamic acids in synthetic media. Applied Microbiology and Biotechnology. 2008;78:997-1006.

32. Bicho NC, Leitão AE, Ramalho JC, De Alvarenga NB, Lidon FC. Identification of nutritional descriptors of roasting intensity in beverages of Arabica and Robusta coffee beans. International Journal of food Science and Nutrition. 2011;62:865-871.

33. Dawidowicz AL, Typek R. The influence of $\mathrm{pH}$ on the thermal stability of 5-O-caffeoylquinic acids in aqueous solutions. European Food Research and Technology. 2011;233:223-232.

34. Kim MJ, John KM, Choi JN, Lee S, Kim AJ, Kim YM, Lee $\mathrm{CH}$. Changes in secondary metabolites of green tea during fermentation by Aspergillus oryzae and its effect on antioxidant potential. Food Research International. 2013;53:670-677. 